\title{
The Expression of p53 and COX-2 in Basal Cell Carcinoma, Squamous Cell Carcinoma and Actinic Keratosis Cases
}

\author{
Bazal Hücreli Karsinom, Skuamöz Hücreli Karsinom ve Aktinik \\ Keratoz Olgularında p53 ve COX-2 Ekspresyonu
}

\author{
Ülker KARAGECE YALÇIN'1, Selda SEÇKIN²
}

Department of Pathology, ${ }^{1}$ M.H. Yozgat State Hospital, YOZGAT, TURKEY, ${ }^{2}$ M.H. Ankara Numune Education and Research Hospital, ANKARA, TURKEY

\begin{abstract}
Objective: The aim of this study was to investigate p53 and COX-2 expressions in basal cell carcinoma, squamous cell carcinoma and actinic keratoses, and to determine a possible relationship.

Material and Method: 50 basal cell carcinoma, 45 squamous cell carcinoma and 45 actinic keratosis cases were evaluated. The type of tumor in basal cell carcinoma and tumor differentiation in squamous cell carcinoma were noted and the paraffin block that best represented the tumor was chosen. Immunostaining by p53 and COX-2 was performed on sections of the paraffin blocks.
\end{abstract}

Results: p53 expression was observed in 98\% of basal cell carcinoma, $88.9 \%$ of squamous cell carcinoma and all actinic keratosis cases. p53 expression was also noted in non-dysplastic appearing epithelium in actinic keratosis cases. COX-2 expression was seen in 90, 100 and $88.9 \%$ of the basal cell carcinoma, squamous cell carcinoma and actinic keratosis groups, respectively. Skin appendages, inflammatory cells and vascular structures were also stained by COX-2 besides tumor tissue. COX-2 expression increased by the p53 expression increase in basal cell carcinoma and squamous cell carcinoma. p53 and COX-2 expressions were not related in terms of tumor type in the BCC and were not related in terms of differentiation in SCC.

Conclusion: The existence of p53 expression in actinic keratosis cases has supported the idea that p53 plays a role in the early steps of carcinogenesis in skin cancers. The fact that the expression of COX-2 increases in line with the increase of p53 expression in basal cell carcinoma and squamous cell carcinoma cases indicates that COX-2 expression may be affected by $\mathrm{p} 53$.

Key Words: Basal cell carcinoma, Squamous cell carcinoma, Actinic keratosis, p53, Cyclooxygenase 2
ÖZ

Amaç: Çalışma bazal hücreli karsinom, skuamöz hücreli karsinom ve aktinik keratoz olgularında p53 ve COX-2 ekspresyonlarını değerlendirmek ve aralarında ilişki olup olmadığını saptamak amaciyla planland.

Gereç ve Yöntem: Çalıșmaya 50 bazal hücreli karsinom, 45 skuamöz hücreli karsinom ve 45 aktinik keratoz olgusu dahil edildi. Bazal hücreli karsinom olgularında tümör tipleri, skuamöz hücreli karsinom olgularında tümör diferansiasyonları belirlenerek tümörü en iyi temsil eden parafin blok seçildi ve immünhistokimyasal yöntem ile p53 ve COX-2 çalışıldı.

Bulgular: p53 ekspresyonu bazal hücreli karsinom olgularının \%98'inde, skuamöz hücreli karsinom olgularının \%88,9'unda ve aktinik keratozlu olguların tamamında izlendi. Aktinik keratoz olgularında hematoksilen-eosin kesitlerde displastik görünmeyen alanlarda da p53 ekspresyonu mevcuttu. COX-2 ekspresyonu bazal hücreli karsinom grubunda \%90, skuamöz hücreli karsinom grubunda $\% 100$, aktinik keratoz grubunda $\% 88,9$ oranında saptandı. COX-2'nin ayrıca tümör dışında deri eklerinde, inflamatuvar hücrelerde ve vasküler yapılarda da eksprese olduğu gözlendi. Bazal hücreli karsinom ve skuamöz hücreli karsinom olgularında p53 ekspresyonu arttıkça COX-2 ekspresyonunun da arttığ 1 saptandı. p53 ve COX-2'nin bazal hücreli karsinomda tümör tipinden, skuamöz hücreli karsinomda diferansiasyondan bağımsız olarak eksprese olduğu görüldü.

Sonuç: Aktinik keratoz olgularında izlenen p53 ekspresyonu, p53'ün keratinositik deri karsinogenezinde erken basamaklarda rol oynadığı görüşünü destekledi. Bazal hücreli karsinom ve skuamöz hücreli karsinom olgularında p53 ekspresyonu arttıkça COX-2 ekspresyonunun da artması COX-2 ekspresyonunu p53'ün etkilediğini düşünmemize neden oldu.

Anahtar Sözcükler: Bazal hücreli karsinom, Skuamöz hücreli karsinom, Aktinik keratoz, p53, Siklooksijenaz 2
(Turk Patoloji Derg 2012, 28:119-127)

Received : 04.03.2011 Accepted : 29.01.2012
Correspondence: Ülker KARAGECE YALÇIN

Department of Pathology, Yozgat State Hospital, YOZGAT, TURKEY

E-mail: karagece@gmail.com Phone: +90 3542121070 


\section{INTRODUCTION}

Skin cancers are the most common malignancies globally and keratinocytic tumors make up $90 \%$ of all skin cancers. Basal cell carcinoma (BCC) makes up more than $70 \%$ of kerotinocytic tumors and is seen 4 to 5 times more frequently than squamous cell carcinoma (SCC). These tumors can develop de novo or following the progression of precursor lesions such as actinic keratosis (AK) (1).

The most common factor in the etiology of keratinocytic tumors is exposure to ultraviolet (UV) light. The relationship between UV light and skin cancer development has first been defined in 1875 and has been proven in the 1950s with the demonstration of DNA mutations that developed due to UV exposure (2). Predisposing factors for these tumors other than UV exposure are smoking, industrial chemical agents, and human papilloma virus (1).

The 553 gene is the most commonly mutated gene in human cancers and a p 53 mutation is reported in more than $50 \%$ of human cancers $(3,4)$. A p53 mutation is frequently reported to develop as a CC-TT base change in keratinocytic skin cancers and the mutation is believed to develop in the early stages of carcinogenesis $(5,6)$.

Immunohistochemistry is one of the methods used to show p53 mutation. p53 has a half life of 6 to 30 minutes and is not normally seen in tissues while it has a longer half life and accumulates in the cell nucleus when it is mutated or activated. p53 expression detected with an immunohistochemical method can be accepted as an indirect indicator of the mutation $(7,8)$.

Cyclooxygenase (COX) is an enzyme that catalyses the conversion of arachidonic acid to prostaglandins, its metabolites. There are two isoforms as COX-1 and COX-2 (9). COX-1 is the structural form and is expressed in many tissues during physiological processes while the inducible form COX-2 is stimulated and expressed with tumor promoters such as UV and various cytokines, growth factors, hypoxia, and activation of various oncogenes (10). COX-2 is known to be expressed in many neoplastic processes, stimulate cell division and angiogenesis, and inhibit apoptosis $(10,11)$.

The relationship between p53 mutation and COX-2 expression in human cancers has been the subject of many studies (12-14). Although the results of these studies are variable, the increased COX-2 expression in skin cancers is also thought to be due to p53 mutation (12).

\section{MATERIAL and METHODS}

A total of 140 cases evaluated at Ankara Numune Training and Research Hospital Department of Pathology consisting of 50 BCC, 45 SCC and 45 AK cases were evaluated in this study. Clinical findings of the cases such as age, gender, tumor localization and macroscopic findings were obtained from the department's archive records and report copies.

The hematoxylin-eosin (H\&E) slides prepared from formalin-fixed paraffin embeded blocks of each case were re-evaluated and tumor types for the BCC cases and tumor differentiation for SCC cases were determined. Age, gender, tumor size and tumor localization were recorded for all tumors. Tumor localization was classified as the head and neck region and other regions. The paraffin blocks that best represented the tumor were selected for immunohistochemical staining. Sections 3-4 micrometers thick were obtained from each block onto adhesive slides and p53 (Neomarkers, clone DO-7) and COX-2 (Neomarkers) were studied with the immunohistochemical method. Colon adenocarcinoma was used as the positive control for both p53 and COX-2. The extensity and staining intensity of the stained cells were semiquantatively evaluated, taking into account nuclear staining for p53 and cytoplasmic staining for COX-2. Staining intensity was evaluated as 0 : no staining, $1+$ : weak staining, and 2+: strong staining while staining extensity was evaluated as 0 : no staining, $1+$ : staining in $1-25 \%$ of the cells, $2+$ : staining in $26-50 \%$ of the cells, $3+$ : staining in $51-75 \%$ of the cells and $4+: 76-100 \%$ of the cells.

The SPSS for Windows 11.5 package software was used for statistical analysis. Descriptive statistics were the mean value for age and median (minimum-maximum) for staining extensity and intensity while qualitative changes were evaluated with the number of observations and percentages. One-Way ANOVA was used to determine the significance of the difference between the mean ages of the groups while Pearson's Chi-Square test was used to evaluate the significance of the difference between tumor size, staining extensity and staining intensity. We merged the rows when the distribution of the numbers to the observations was not suitable for Chi-Square test. We performed multiple comparison tests to determine the group(s) responsible for the significance when the Pearson's Chi-Square test statistical result provided a significant value. Qualitative variables were evaluated with Pearson's Chi-Square or Fisher's Exact Chi-Square test. Spearman's Correlation test was used to determine the significance of the correlation between p53 and COX-2 staining intensity and extensity, both within themselves and with age, size and differentiation. The Mann-Whitney $U$ test was used to determine whether a significant change was present in the staining extensity and intensity for p53 and COX-2 by 
gender within the groups. A $p$ value $\mathrm{p}<0.05$ was considered as statistically significant for the results.

\section{RESULTS}

There were 22 female and 28 male BCC cases with a mean age of 66.86 (38-91 years). The tumor was localized to the head and neck region in 46 and the mean tumor size was $1.1 \mathrm{~cm}(0.3-2.8 \mathrm{~cm})$. There were 19 females and 26 males in the SCC group. The mean age was 68.56 years (14-91 years). The tumor was localized to the head and neck in 34 and other regions in 11 and the mean tumor size was $2.6 \mathrm{~cm}$ $(0.3-10.1 \mathrm{~cm})$. The mean age of the AK group was 65.73 years (14-87 years) with 21 females and 24 males and the tumor was localized to the head and neck region in 42 cases. The mean AK tumor size was $0.76 \mathrm{~cm}(0.1-3 \mathrm{~cm})$. The age and gender was similar in all three groups and the tumors were most commonly localized to the head and neck region. The SCC cases had the largest tumor size (Table I).

Regarding tumor type, the BCC group had 29 (58\%) nodular type and $10(20 \%)$ infiltrative type tumors. The tumor was metatypical in $5(10 \%)$, keratotic in $2(4 \%)$, morpheiform in $2(4 \%)$ and superficial type BCC in $2(4 \%)$ cases. The infiltrative, metatypical and morpheiform type BCC cases were accepted as aggressive and the other types as nonaggressive. The SCC cases were distributed according to differentiation as follows: 35 (77.8\%) well differentiated, $8(17.8 \%)$ moderately differentiated and $2(4.4 \%)$ poorly differentiated.

p53 expression was present in 49 (98\%) BCC cases (Figure 1), 40 (88.9\%) SCC cases and all (100\%) AK cases (Figure 2). COX-2 staining was not present in 5 (\%10)

Table I: Demographic data of the cases

\begin{tabular}{|c|c|c|c|c|}
\hline Tumor (n) & $\begin{array}{c}\text { Gender } \\
\text { F/M }\end{array}$ & $\begin{array}{c}\text { Age } \\
\text { Mean } \pm \text { SD }\end{array}$ & $\begin{array}{c}\text { Localization } \\
\text { Head-neck/Other }\end{array}$ & $\begin{array}{c}\text { Size } \\
\text { Mean } \pm \text { SD }\end{array}$ \\
\hline BCC (50) & $22 / 28$ & $66.9 \pm 11.7$ & $46 / 4$ & $1.1 \pm 0.7$ \\
\hline SCC (45) & $19 / 26$ & $68.6 \pm 15.8$ & $34 / 11$ & $2.6 \pm 2.8$ \\
\hline AK (45) & $21 / 24$ & $65.7 \pm 15.5$ & $42 / 3$ & $0.8 \pm 0.7$ \\
\hline
\end{tabular}

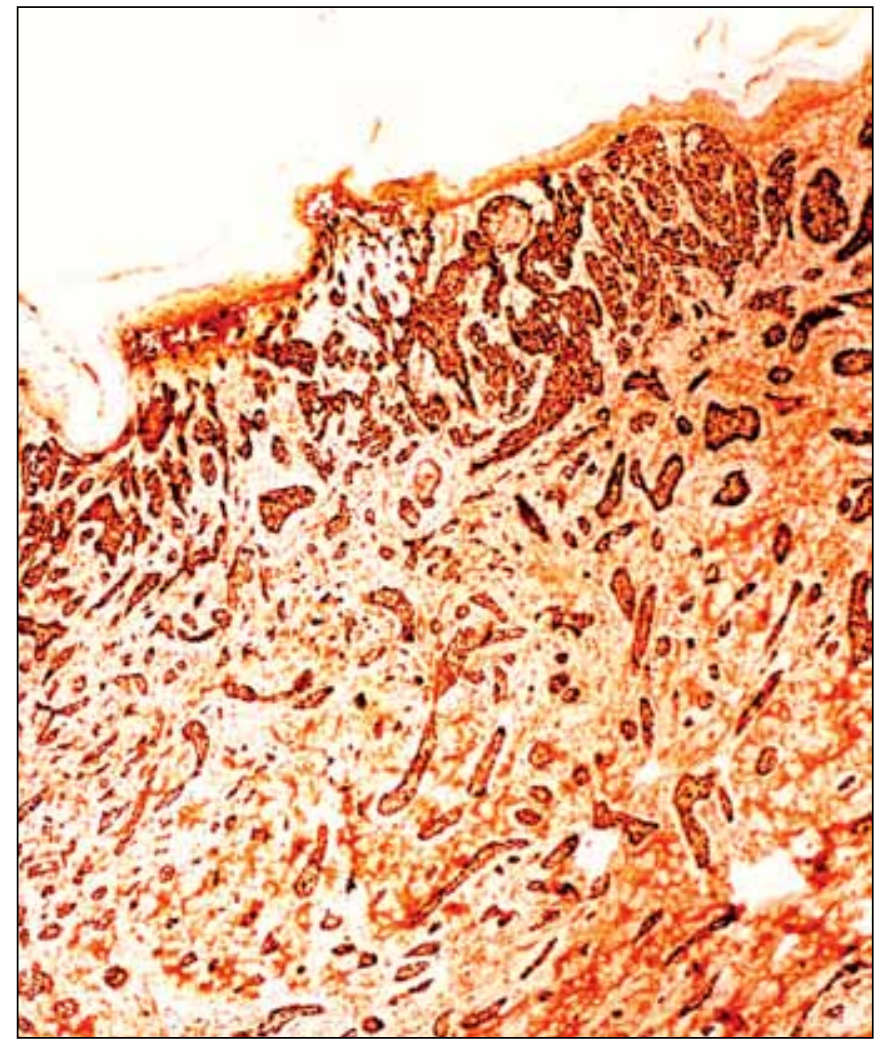

Figure 1: p53 staining with 4+ extensity in infiltrative basal cell carcinoma $(\mathrm{x} 40)$.

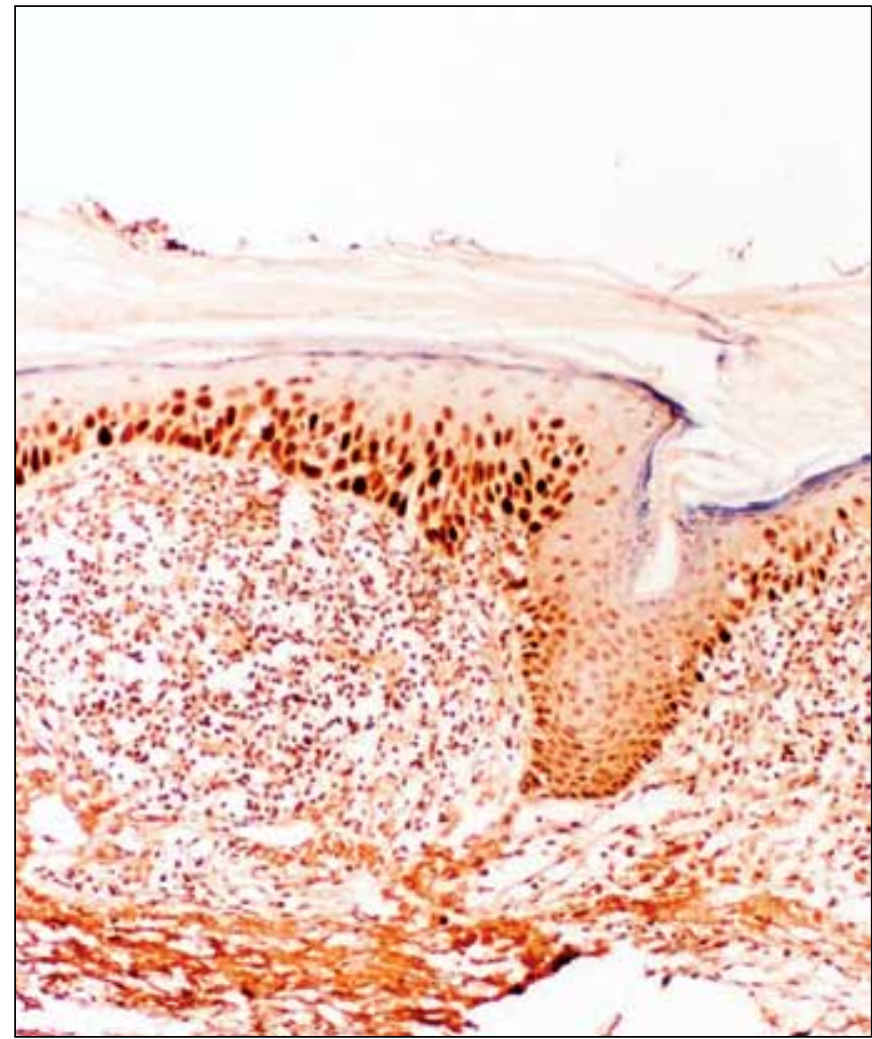

Figure 2: p53 staining with 4+ extensity in actinic keratosis (x100). 
BCC and 5 (11.1\%) AK cases while COX-2 expression was present in all SCC cases (Figure 3).

Table II presents the distribution of p53 and COX-2 expressions in BCC, SCC and AK cases and the comparison using Pearson's Chi-Square test. There were $16(36 \%)$ cases in the SCC group and $4(8 \%)$ cases in the BCC group with $1+/ 2+(1-50 \%)$ staining extensity by $\mathrm{p} 53$. The difference

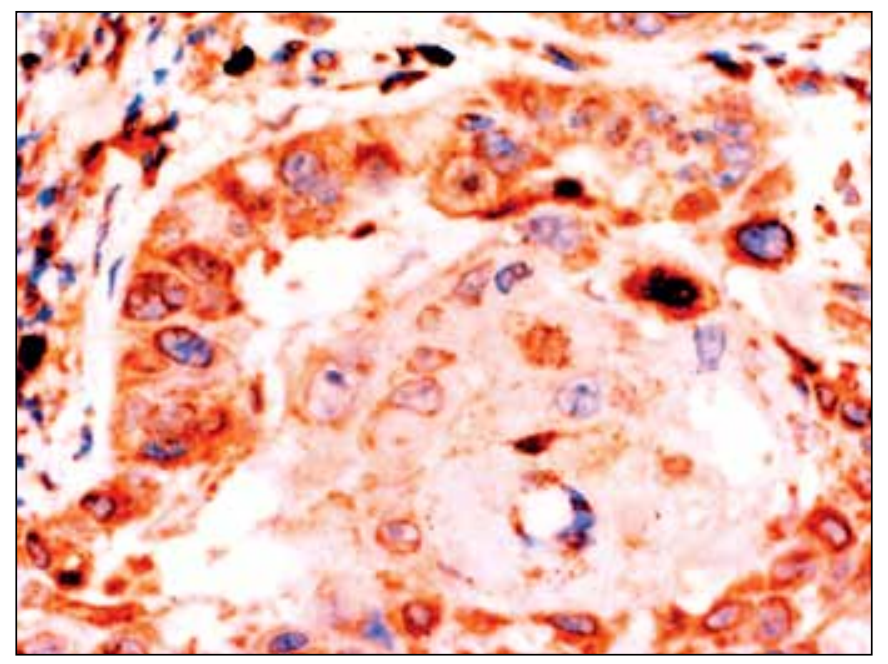

Figure 3: COX-2 staining at 2+ extensity in well-differentiated squamous cell carcinoma (x400). was statistically significant $(\mathrm{p}<0.001)$. Comparison of the BCC and AK and the SCC and AK groups showed no statistically significant difference. The extend of staining by COX-2 showed cytoplasmic COX-2 expression of 4+ extensity in $12 \%$ of BCC cases, $51 \%$ of SCC cases and $51 \%$ of AK cases. The analysis showed a statistically significant difference between the groups and COX-2 expression was more extensive in SCC and AK than in BCC. We found $2+$ staining intensity by p53 in $30 \%$ of BCC, $62 \%$ of SCC and $71 \%$ of AK cases. Multiple comparisons of the groups exhibited that p53 expression was weaker in BCC cases than in SCC and AK cases. We also noted that p53 staining was denser at the peripheral areas of the tumor islands in well-differentiated SCC cases (Figure 4). COX-2 staining intensity was strong (2+) in $10 \%$ of BCC, $32 \%$ of SCC, and $16 \%$ of $\mathrm{AK}$ group cases and we appointed a statistically significant difference between SCC and BCC.

Strong (2+ intensity) p53 staining with $4+$ extensity was present in 12 BCC group cases (Table III). The number of cases with $4+$ staining extensity by p 53 and COX-2 were 6 in this group (Table IV) while 30 cases showed weak (1+ intensity) expression with both p53 and COX-2 (Table V). There were weak and 1+ extensity COX-2 expression in 21 BCC cases. In the SCC group, there were 11 cases with weak

Table II: Distribution and comparison of p53 and COX-2 staining in BCC, SCC and AK cases

\begin{tabular}{|c|c|c|c|c|c|c|c|}
\hline & \multirow{2}{*}{ BCC } & \multirow{2}{*}{ SCC } & \multirow{2}{*}{ AK } & \multirow{2}{*}{$\mathbf{p}$} & \multicolumn{3}{|c|}{ Multiple comparisons } \\
\hline & & & & & BCC-SCC & BCC-AK & SCC-AK \\
\hline \multicolumn{8}{|c|}{ p53 staining extensity } \\
\hline 0 & $1(2 \%)$ & $4(9 \%)$ & $0(0 \%)$ & 0.057 & - & - & - \\
\hline $1+/ 2+$ & $4(8 \%)$ & $16(36 \%)$ & $9(20 \%)$ & 0.004 & $\mathrm{p}<0.001$ & $\mathrm{p}=0.089$ & $\mathrm{p}=0.099$ \\
\hline $3+$ & $16(32 \%)$ & $8(18 \%)$ & $9(20 \%)$ & 0.209 & - & - & - \\
\hline $4+$ & $29(58 \%)$ & $17(37 \%)$ & $27(60 \%)$ & 0.063 & - & - & - \\
\hline \multicolumn{8}{|c|}{ COX-2 staining extensity } \\
\hline 0 & $5(10 \%)$ & $0(0 \%)$ & $5(11 \%)$ & 0.076 & - & - & - \\
\hline $1+/ 2+$ & $28(56 \%)$ & $12(27 \%)$ & $9(20 \%)$ & $<0.001$ & $\mathrm{p}=0.004$ & $\mathrm{p}<0.001$ & $\mathrm{p}=0.455$ \\
\hline $3+$ & $11(22 \%)$ & $10(22 \%)$ & $5(11 \%)$ & 0.295 & - & - & - \\
\hline $4+$ & $6(12 \%)$ & $23(51 \%)$ & $26(58 \%)$ & $<0.001$ & $\mathrm{p}<0.001$ & $\mathrm{p}<0.001$ & $\mathrm{p}=0.525$ \\
\hline \multicolumn{8}{|c|}{ p53 staining intensity } \\
\hline 0 & $1(2 \%)$ & $5(11 \%)$ & $0(0 \%)$ & 0.021 & $\mathrm{p}=0.098$ & $\mathrm{p}=1.000$ & $\mathrm{p}=0.056$ \\
\hline $1+$ & $34(68 \%)$ & $12(27 \%)$ & $13(29 \%)$ & $<0.001$ & $\mathrm{p}<0.001$ & $\mathrm{p}<0.001$ & $\mathrm{p}=0.814$ \\
\hline $2+$ & $15(30 \%)$ & $28(62 \%)$ & $32(71 \%)$ & $<0.001$ & $\mathrm{p}=0.002$ & $\mathrm{p}<0.001$ & $\mathrm{p}=0.371$ \\
\hline \multicolumn{8}{|c|}{ COX-2 staining intensity } \\
\hline 0 & $5(10 \%)$ & $0(0 \%)$ & $5(11 \%)$ & 0.076 & - & - & - \\
\hline $1+$ & $40(80 \%)$ & $31(69 \%)$ & $33(73 \%)$ & 0.458 & - & - & - \\
\hline $2+$ & $5(10 \%)$ & $14(31 \%)$ & $7(16 \%)$ & 0.025 & $\mathrm{p}=0.019$ & $\mathrm{p}=0.416$ & $\mathrm{p}=0.081$ \\
\hline Total & $50(100 \%)$ & $45(100 \%)$ & $45(100 \%)$ & - & - & - & - \\
\hline
\end{tabular}




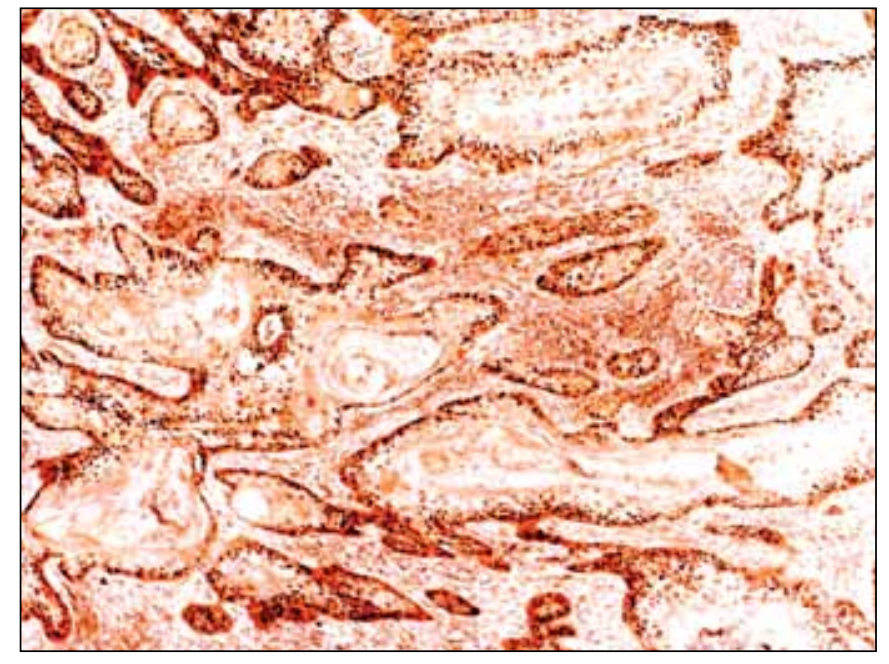

Figure 4: p53 staining at the periphery of tumor islands of well differantiated squamous cell carcinoma (x100). and 1+ staining extensity and 16 cases with strong and 4+ staining extensity by p53 (Table VI). There were also 13 cases with diffuse ( $4+$ extensity) p53 and COX-2 expression. (Table VII). Table VIII presents the distribution of AK cases among the COX-2 staining extensity and intensity.

In BCC cases, p53 staining intensity increased with increasing extensity $(\mathrm{p}=0.011)$, while $\mathrm{COX}-2$ staining extensity increased with p53 staining extensity and COX2 staining intensity similarly increased with p53 staining intensity ( $\mathrm{p}<0.007, \mathrm{p}<0.001)$. The COX-2 staining extensity and intensity were also correlated $(\mathrm{p}<0.001)$. In SCC cases, increasing p53 staining extensity meant increasing intensity $(\mathrm{p}<0.001)$ and there was also a positive correlation between p53 and COX-2 extensity $(\mathrm{p}<0.001)$. In AK cases, we only found a statistically significant relationship between COX2 expression intensity and extensity $(\mathrm{p}=0.007)$ (Table IX).

Table III: Distribution of p53 staining extensity and intensity in BCC cases

\begin{tabular}{|c|c|c|c|c|}
\hline \multirow{2}{*}{ BCC } & \multicolumn{2}{c|}{ p53 intensity n (\%) } & \multirow{2}{*}{ Total n (\%) } \\
\cline { 3 - 5 } & $1+$ & $1+$ & $2+$ & $1(2 \%)$ \\
\hline \multirow{3}{*}{ p53 extensity } & $1+2 \%)$ & $0(0 \%)$ & $4(8 \%)$ \\
\cline { 2 - 5 } & & $4(8 \%)$ & $0(0 \%)$ & $16(32 \%)$ \\
\cline { 2 - 5 } & & $13(26 \%)$ & $3(6 \%)$ & $29(58 \%)$ \\
\cline { 2 - 5 } & & $17(34 \%)$ & $12(24 \%)$ & $50(100 \%)$ \\
\hline \multicolumn{2}{|c|}{ Total } & $35(70 \%)$ & $15(30 \%)$ & \\
\hline
\end{tabular}

Table IV: Distribution of p53 staining extensity and COX-2 staining extensity in BCC cases

\begin{tabular}{|c|c|c|c|c|c|c|c|}
\hline \multirow{2}{*}{\multicolumn{2}{|c|}{ BCC }} & \multicolumn{5}{|c|}{ COX-2 extensity n (\%) } & \multirow{2}{*}{ Total n (\%) } \\
\hline & & \multirow{2}{*}{$\begin{array}{c}\mathbf{0} \\
1(2 \%)\end{array}$} & \multirow{2}{*}{$\frac{1+}{0(0 \%)}$} & \multirow{2}{*}{$\begin{array}{c}\mathbf{2 +} \\
0(0 \%)\end{array}$} & \multirow{2}{*}{$\begin{array}{c}\mathbf{3 +} \\
0(0 \%)\end{array}$} & \multirow{2}{*}{$\frac{4+}{0(0 \%)}$} & \\
\hline \multirow{5}{*}{ p53 extensity } & 0 & & & & & & $1(2 \%)$ \\
\hline & $1+$ & $0(0 \%)$ & $0(0 \%)$ & $0(0 \%)$ & $0(0 \%)$ & $0(0 \%)$ & $0(0 \%)$ \\
\hline & $2+$ & $2(4 \%)$ & $2(4 \%)$ & $0(0 \%)$ & $0(0 \%)$ & $0(0 \%)$ & $4(8 \%)$ \\
\hline & $3+$ & $1(2 \%)$ & $6(12 \%)$ & $4(8 \%)$ & $5(10 \%)$ & $0(0 \%)$ & $16(32 \%)$ \\
\hline & $4+$ & $1(2 \%)$ & $9(18 \%)$ & $7(14 \%)$ & $6(12 \%)$ & $6(12 \%)$ & $29(58 \%)$ \\
\hline \multicolumn{2}{|c|}{ Total } & $5(10 \%)$ & $17(34 \%)$ & $11(22 \%)$ & $11(22 \%)$ & $6(12 \%)$ & $50(100 \%)$ \\
\hline
\end{tabular}

Table V: Distribution of p53 and COX-2 staining intensity in BCC cases

\begin{tabular}{|c|c|c|c|c|c|}
\hline \multirow{2}{*}{\multicolumn{2}{|c|}{ BCC }} & \multicolumn{3}{|c|}{ COX-2 intensity $n(\%)$} & \multirow{3}{*}{$\begin{array}{c}\text { Total n (\%) } \\
1(2 \%)\end{array}$} \\
\hline & & \multirow{2}{*}{$\begin{array}{c}\mathbf{0} \\
1(2 \%) \\
\end{array}$} & \multirow{2}{*}{$\begin{array}{c}\mathbf{1 +} \\
0(0 \%) \\
\end{array}$} & \multirow{2}{*}{$\frac{2+}{0(0 \%)}$} & \\
\hline \multirow{3}{*}{ p53 intensity } & 0 & & & & \\
\hline & $1+$ & $4(8 \%)$ & $30(60 \%)$ & $0(0 \%)$ & $34(68 \%)$ \\
\hline & $2+$ & $0(0 \%)$ & $10(20 \%)$ & $5(10 \%)$ & $15(30 \%)$ \\
\hline \multicolumn{2}{|c|}{ Total } & $5(10 \%)$ & $40(80 \%)$ & $5(10 \%)$ & $50(100 \%)$ \\
\hline
\end{tabular}


Table VI: Distribution of p53 staining extensity and p53 staining intensity in SCC cases

\begin{tabular}{|c|c|c|c|c|}
\hline \multirow{2}{*}{\multicolumn{2}{|c|}{ SCC }} & \multicolumn{2}{|c|}{ p53 intensity n (\%) } & \multirow{3}{*}{$\begin{array}{c}\text { Total n (\%) } \\
13(28.88 \%) \\
\end{array}$} \\
\hline & & \multirow{2}{*}{$\begin{array}{c}1+ \\
11(24.44 \%)\end{array}$} & \multirow{2}{*}{$\begin{array}{c}\mathbf{2 +} \\
2(4.44) \\
\end{array}$} & \\
\hline \multirow{4}{*}{ p53 extensity } & $1+$ & & & \\
\hline & $2+$ & $4(8.89 \%)$ & $4(8.89 \%)$ & $8(17.78 \%)$ \\
\hline & $3+$ & $2(4.44 \%)$ & $6(13.33 \%)$ & $8(17.78 \%)$ \\
\hline & $4+$ & $0(0 \%)$ & $16(35.56 \%)$ & $16(35.56 \%)$ \\
\hline \multicolumn{2}{|c|}{ Total } & $17(37.77 \%)$ & $28(62.22 \%)$ & $45(\% 100)$ \\
\hline
\end{tabular}

Table VII: Distribution of p53 and COX-2 staining extensity in SCC cases

\begin{tabular}{|c|c|c|c|c|c|c|c|}
\hline \multirow{2}{*}{ SCC } & \multicolumn{5}{c|}{ COX-2 extensity n (\%) } & \multirow{2}{*}{ Total n (\%) } \\
\cline { 3 - 7 } & & $\mathbf{0}$ & $\mathbf{1 +}$ & $\mathbf{2 +}$ & $\mathbf{3 +}$ & $\mathbf{4 +}$ & \multicolumn{1}{|c|}{} \\
\hline \multirow{3}{*}{$\mathrm{p} 53$ extensity } & 0 & $0(0 \%)$ & $2(4.44 \%)$ & $1(2.22 \%)$ & $0(0 \%)$ & $2(4.44 \%)$ & $5(11.11 \%)$ \\
\cline { 2 - 7 } & $1+$ & $0(0 \%)$ & $4(8.89 \%)$ & $2(4.44 \%)$ & $0(0 \%)$ & $2(4.44 \%)$ & $8(17.78 \%)$ \\
\cline { 2 - 7 } & $2+$ & $0(0 \%)$ & $1(2.22 \%)$ & $2(4.44 \%)$ & $1(2.22 \%)$ & $4(8.89 \%)$ & $8(17.78 \%)$ \\
\cline { 2 - 8 } & $3+$ & $0(0 \%)$ & $0(0 \%)$ & $0(0 \%)$ & $6(13.33 \%)$ & $2(4.44 \%)$ & $8(17.78 \%)$ \\
\cline { 2 - 8 } & $4+$ & $0(0 \%)$ & $0(0 \%)$ & $0(0 \%)$ & $3(6.67 \%)$ & $13(28.89 \%)$ & $16(\% 35.56)$ \\
\hline \multicolumn{2}{|c|}{ Total } & $0(0 \%)$ & $7(15.55 \%)$ & $5(11.11 \%)$ & $10(22.22 \%)$ & $23(51.11 \%)$ & $45(\% 99.99)$ \\
\hline
\end{tabular}

Table VIII: Distribution of COX-2 staining extensity and intensity in AK cases

\begin{tabular}{|c|c|c|c|c|}
\hline \multirow{2}{*}{\multicolumn{2}{|c|}{ AK }} & \multicolumn{2}{|c|}{ COX-2 intensity n (\%) } & \multirow{3}{*}{$\begin{array}{l}\text { Total n (\%) } \\
8(17.78 \%) \\
\end{array}$} \\
\hline & & \multirow{2}{*}{$\begin{array}{c}\mathbf{1 +} \\
8(17.78 \%) \\
\end{array}$} & \multirow{2}{*}{$\begin{array}{r}2+ \\
0(0 \%) \\
\end{array}$} & \\
\hline \multirow{3}{*}{ COX-2 extensity } & $1+$ & & & \\
\hline & $3+$ & $4(8.89 \%)$ & $1(2.22 \%)$ & $5(11.11 \%)$ \\
\hline & $4+$ & $22(48.89 \%)$ & $4(8.89 \%)$ & $26(57.78 \%)$ \\
\hline
\end{tabular}

Table IX: Correlation coefficients (r) and significance levels (p) between p53 and COX-2 in BCC, SCC and AK groups

\begin{tabular}{|c|c|c|c|c|c|c|c|c|c|}
\hline \multirow{2}{*}{\multicolumn{2}{|c|}{ Variables }} & \multicolumn{2}{|c|}{ p53 extensity } & \multicolumn{2}{|c|}{ p53 intensity } & \multicolumn{2}{|c|}{ COX-2 extensity } & \multicolumn{2}{|c|}{ COX-2 intensity } \\
\hline & & $\mathbf{r}$ & $\mathbf{p}$ & $\mathbf{r}$ & $\mathbf{p}$ & $\mathbf{r}$ & $\mathbf{p}$ & $\mathbf{R}$ & $\mathbf{p}$ \\
\hline \multirow{3}{*}{$\mathrm{BCC}$} & p53 extensity & 1.000 & - & 0.355 & 0.011 & 0.374 & 0.007 & 0.273 & 0.055 \\
\hline & COX-2 extensity & 0.374 & 0.007 & 0.183 & 0.204 & 1.000 & - & 0.453 & $<0.001$ \\
\hline & COX-2 intensity & 0.273 & 0.055 & 0.535 & $<0.001$ & 0.453 & $<0.001$ & 1.000 & - \\
\hline \multirow{3}{*}{ SCC } & p53 intensity & 0.761 & $<0.001$ & 1.000 & - & 0.192 & 0.206 & 0.045 & 0.768 \\
\hline & COX-2 extensity & 0.517 & $<0.001$ & 0.192 & 0.206 & 1.000 & - & 0.142 & 0.351 \\
\hline & COX-2 intensity & 0.002 & 0.990 & 0.045 & 0.768 & 0.142 & 0.351 & 1.000 & - \\
\hline \multirow{2}{*}{$\mathrm{AK}$} & p53 extensity & 1.000 & - & 0.231 & 0.127 & 0.041 & 0.789 & 0.292 & 0.051 \\
\hline & p53 intensity & 0.231 & 0.127 & 1.000 & - & 0.143 & 0.348 & -0.141 & 0.355 \\
\hline
\end{tabular}


We also noted that COX-2 was expressed not only in the dysplastic epithelium but also in inflammatory cells and vessel walls in all three groups (Figure 5).

We did not find a statistically significant relationship between patient age and tumor size and p53 and COX-2 staining extensity and intensity in the BCC groups. Patient age had no effect on p53 and COX-2 expression in SCC group while a positive correlation was present between tumor size and COX-2 intensity ( $\mathrm{p}=0.020)$. In AK patients, p53 expression extensity and COX-2 expression intensity increased with patient age $(\mathrm{p}=0.006, \mathrm{p}=0.004)$. In AK cases there was also a weak correlation between tumor size and

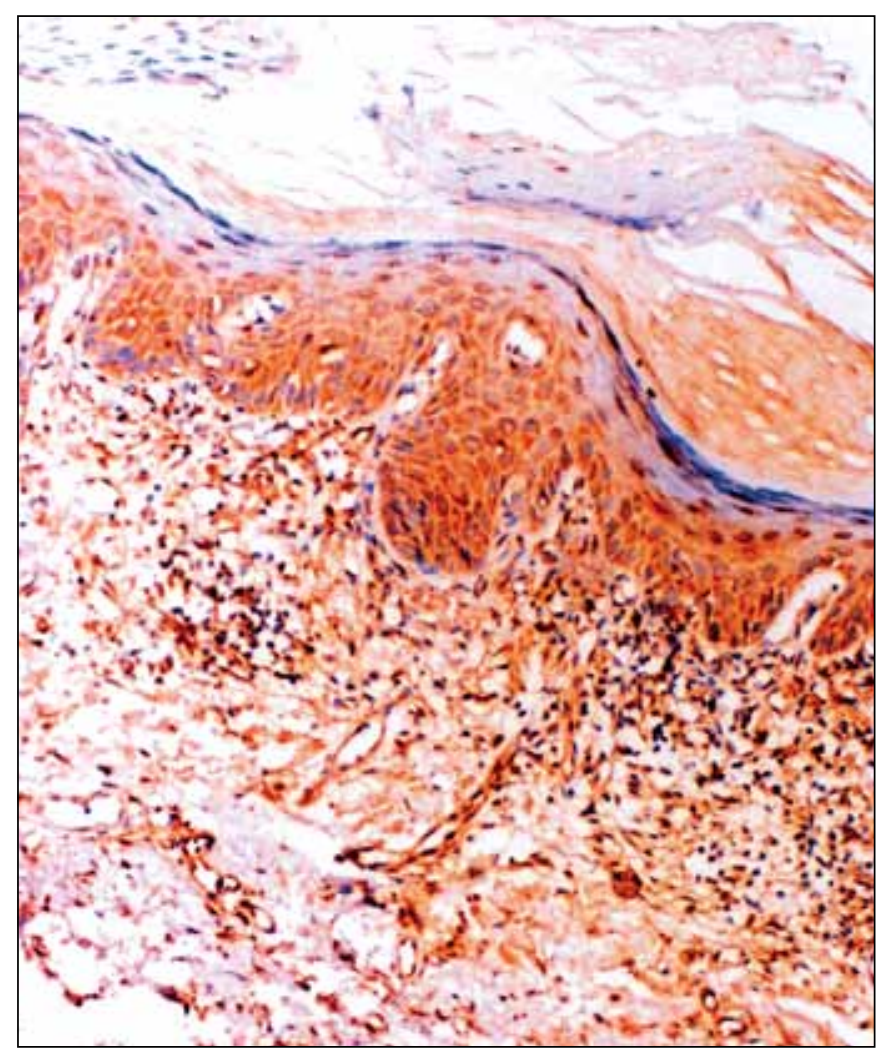

Figure 5: Vascular and inflammatory cell straining besides weak (1+) staining with COX-2 in actinic keratosis epithelium (x40). p53 density ( $\mathrm{p}=0.048)$ while tumor size had no effect on COX-2 expression (Table X). There was no effect of gender on p53 or COX-2 expression in all groups. We did not find a statistically significant difference between p53 and COX-2 expression with aggressive and non-aggressive BCC groups and with tumor differentiation in SCC cases.

\section{DISCUSSION}

Keratinocytic skin cancers develop mainly as a result of exposure to ultraviolet (UV) light and are the most common malignancies globally. These tumors are generally seen in advanced ages in male patients and in skin exposed to sun such as head and neck. (1).

UVB makes up 1-10\% of the UV rays reaching the earth while $90 \%$ are UVA. UVB rays cause genotoxicity and p53 gene mutations when absorbed by the keratinocyte DNA (15). The p53 expression that is detected by the immunohistochemical method can be accepted as indirect indicator of mutation. Khorshid et al reported that finding p53 expression in more than $50 \%$ of tumor cells can be correlated with mutation (8). It is believed that 553 mutation develops in the early stages of skin carcinogenesis. There are also studies that show p53 mutation in AK cases and in skin with normal appearance that has been exposed to the sun $(5,16)$. We found $\mathrm{p} 53$ expression in all our AK cases. As well as interesting we determinated $\mathrm{p} 53$ expression in areas that did not show dysplasia on H\&E slides. These results indicate that p53 plays a role in the early stages of skin carcinogenesis. We also found that p53 expression extensity increases with advanced patient age in $\mathrm{AK}$ cases and we believe that this could be due to prolonged UV exposure.

We found p53 expression in 49 (98\%) of our BCC cases. There was no statistically significant difference for p53 expression, extensity and intensity among BCC types. De Rosa et al. and Ansarin et al. investigated p53 expression in aggressive and non-aggressive variants of $\mathrm{BCC}$ and reported markedly higher p53 expression in the aggressive group, stating that $\mathrm{p} 53$ expression could be a prognostic parameter

Table X: Correlation coefficients ( $\mathrm{r}$ ) and significance level (p) between $\mathrm{p} 53$ and COX-2 extensity and intensity levels and patient age in BCC, SCC and AK groups

\begin{tabular}{|c|c|c|c|c|c|c|c|c|c|c|c|c|}
\hline \multirow{3}{*}{ Variables } & \multicolumn{4}{|c|}{ BCC } & \multicolumn{4}{|c|}{ SCC } & \multicolumn{4}{|c|}{ AK } \\
\hline & \multicolumn{2}{|c|}{ Age } & \multicolumn{2}{|c|}{ Dimension } & \multicolumn{2}{|c|}{ Age } & \multicolumn{2}{|c|}{ Dimension } & \multicolumn{2}{|c|}{ Age } & \multicolumn{2}{|c|}{ Dimension } \\
\hline & $\mathbf{r}$ & $\mathbf{p}$ & $\mathbf{r}$ & $\mathbf{p}$ & $\mathbf{r}$ & $\mathbf{p}$ & $\mathbf{r}$ & $\mathbf{p}$ & $\mathbf{r}$ & $\mathbf{p}$ & $\mathbf{r}$ & $\mathbf{p}$ \\
\hline p53 extensity & 0.217 & 0.130 & -0.142 & 0.325 & 0.241 & 0.110 & -0.287 & 0.056 & 0.404 & 0.006 & -0.052 & 0.733 \\
\hline p53 intensity & 0.271 & 0.057 & 0.104 & 0.471 & 0.032 & 0.832 & -0.244 & 0.106 & 0.178 & 0.243 & -0.296 & 0.048 \\
\hline COX 2 extensity & 0.083 & 0.567 & -0.091 & 0.529 & 0.266 & 0.077 & -0.168 & 0.270 & 0.295 & 0.049 & -0.130 & 0.394 \\
\hline COX 2 intensity & 0.056 & 0.700 & 0.031 & 0.830 & 0.009 & 0.952 & 0.346 & 0.020 & 0.425 & 0.004 & -0.128 & 0.400 \\
\hline
\end{tabular}


in BCC cases $(17,18)$. However, Healy et al. did not find a significant difference between the two groups (19). We also did not find a difference regarding p53 expression between aggressive and non-aggressive variants in our study.

Lee et al. and Gusterson et al. evaluated p53 expression in SCC cases and found a marked p53 expression in the undifferentiated cells at the periphery of tumor islands $(20,21)$. We also found diffuse p53 staining in moderately and poorly differentiated SCC cases while p53 staining was limited to the periphery of keratinized tumor islands in well-differentiated tumors.

Comparison of the groups for p53 expression extensity in our study showed a larger number of SCC cases than BCC cases with $1+/ 2+(1-50 \%)$ staining extensity. We feel that this may be related to the fact that most SCC cases in our study were well-differentiated tumors with widespread keratinization.

Another molecule thought to play a role in skin carcinogenesis is COX-2. Some studies have reported COX-2 expression in skin appendages and vessel walls in addition to tumor cells $(22,23)$. We determinated COX-2 expression with variable extensity and intesity in all groups of our study. We also noticed COX-2 staining in pilosebaceous units, vessel walls and inflammatory cells. We found no difference for COX-2 expression between the aggressive and non-aggressive BCC cases. There was also no statistically significant difference for COX-2 expression between well, moderate and poorly differentiated SCC tumors while COX-2 staining increased with tumor size. Significantly lower COX-2 extensity in BCC group compared to SCC and $\mathrm{AK}$ and lower COX-2 in BCC compared to SCC may indicate that COX-2 has a minor role in SCC and AK development than in BCC.

Although it is not clear what mechanisms play role in the carcinogenesis related to COX-2, Subbaramaiah et al. postulated that COX-2 expression may be a result of p53 mutation (12). We found increased COX-2 expression extensity with increased $\mathrm{p} 53$ expression extensity in the BCC and SCC cases in our study. These findings indicate that p53 mutation may possibly play a role in skin carcinogenesis through a mechanism that also includes COX-2.

\section{REFERENCES}

1. Weedon D, Marks R, Kao GF, Harword CA: Keratinocytic Tumours. In LeBoit PE, Burg G, Weedon D, Sarasin A. (Eds): World Health Organization Classification of Tumours. Pathology \& Genetics of Skin Tumours. Lyon, IARC Press, 2006, 10-48
2. Boukamp P: UV-induced skin cancer: Similarities variations. J Dtsch Dermatol Ges 2005, 3:493-503

3. Giglia-Mari G, Sarasin A: TP53 mutations in human skin cancers. Hum Mutat 2003, 21:217-228

4. Collot-Teixeira S, Bass J, Denis F, Ranger-Rogez S: Human tumor suppressor p53 and DNA viruses. Rev Med Virol 2004, 14:301-319

5. Nakazawa H, English D, Randell PL, Nakazawa K, Martel N, Armstrong BK, Yamasaki H: UV and skin cancer: Specific p53 gene mutation in normal skin as a biologically relevant exposure measurement. Proc Natl Acad Sci 1994, 91: 360-364

6. Nagano T, Ueda M, Ichihashi M: Expression of p53 protein is an early event in ultraviolet light-induced cutaneous squamous cell carcinogenesis. Arch Dermatol 1993, 129: 1157-1161

7. Greenblatt MS, Bennett WP, Hollstein M, Harris CC: Mutations in the p53 tumor suppressor gene: clues to cancer etiology and molecular pathogenesis. Cancer Res 1994, 54:4855-4878

8. Khorshid SM, Glover MT, Churchill L, McGregor JM, Proby CM: p53 immunoreactivity in non-melanoma skin cancer from immunosuppressed and immunocompetent individuals: a comparative study of 246 tumours. J Cutan Pathol 1996, 23:229-233

9. Williams CS, Mann M, DuBois RN: The role of cyclooxygenases in inflammation, cancer, and development. Oncogene 1999, 18: 7908-7916

10. Fosslien E: Molecular pathology of cyclooxygenase-2 in neoplasia. Ann Clin Lab Sci 2000, 30: 3-21

11. Zhan H, Zheng H: The role of topical cyclo-oxygenase-2 inhibitors in skin cancer. Am J Clin Dermatol 2007, 8(4): 195-200

12. Subbaramaiah K, Altorki N, Chung WJ, Mestre JR, Sampat A, Dannenberg AJ: Inhibition cyclooxygenase-2 gene expression by p53. J Biol Chem 1999, 274:10911-10915

13. Kim KH, Park EJ, Seo YJ, Cho HS, Kim CW, Kim KJ, Park HR: Immunohistochemical study of cyclooxygenase-2 and p53 expression in skin tumors. J Dermatol 2006, 33:319-325

14. Gallo O, Schiavone N, Papucci L, Sardi I, Magnelli L, Franchi A, Masini E, Capaccioli S: Down-regulation of nitric oxide synthase- 2 and cyclooxygenase- 2 pathways by p53 in squamous cell carcinoma. Am J Pathol 2003, 163: 723-732

15. Rass K, Reichrath J: UV damage and repair in malignant melanoma and nonmelanoma skin cancer. Adv Exp Med Biol 2008, 624: 162-178

16. Jonason AS, Kunala S, Price GJ, Restifo RJ, Spinelli HM, Persing JA, Leffell DJ, Tarone RE, Brash DE: Frequent Clones of p53-mutated keratinocytes in normal human skin. Proc Natl Acad Sci 1996, 93:14025-14029

17. De Rosa G, Staibano S, Barra E, Donofrio V, Salvatore G, Vessecchia G, Boscaino A: p53 protein in aggressive and non-aggressive basal cell carcinoma. J Cutan Pathol 1993, 20: 429-434 
18. Ansarin H, Daliri M, Soltani-Arabshahi R: Expression of p53 in aggressive and non-aggressive histologic variants of basal cell carcinoma. Eur J Dermatol 2006, 16:543-547

19. Healy E, Angus B, Lawrence CM, Rees JL: Prognostic value of Ki67 antigen expression in basal cell carcinomas. Br J Dermatol 1995, 133:737-741

20. Lee YS, Teh M: p53 expression in pseudoepitheliomatous hyperplasia, keratoacanthoma and squamous cell carcinoma of skin. Cancer 1994, 73:2317-2323
21. Gusterson BA, Anbazhagan R, Warren W, Midgely C, Lane DP, O'Hare M, Stamps A, Carter R, Jayatilake H: Expression of p53 in premalignant and malignant squamous epithelium. Oncogene 1991, 6:1785-1789

22. Kagoura M, Toyoda M, Matsui C, Morohashi M: Immunohistochemical expression of cyclooxygenase- 2 in skin cancers. J Cutan Pathol 2001, 28:298-302

23. Xu Y, Yang L, Yang T, Xiang M, Huang E, Lian X: Expression pattern of cyclooxygenase-2 in normal rat epidermis and pilosebaceous unit during hair cycle. Acta Histochem Cytochem 2008, 41:157-163 